JURNAL KETAHANAN NASIONAL

P-ISSN: 0853-9340, e-ISSN: 2527-9688

Online sejak 28 Desember 2015 di: http://jurnal.ugm.ac.id/JKN

VOLUME 22

No. 2, 25 Agustus 2016

Halaman 158-179

\title{
MANAJEMEN KOPERASI DALAM RANGKA PENGELOLAAN HUTAN RAKYAT DAN PENGARUHNYA TERHADAP KETAHANAN EKONOMI MASYARAKAT (Studi Pada Koperasi Wana Lestari Menoreh di Kabupaten Kulon Progo, DIY)
}

\author{
Imam Subekti \\ Direktorat Zeni TNI AD \\ Email: imam.subekti@mail.ugm.ac.id \\ Edhi Martono \\ Fakultas Pertanian Universitas Gadjah Mada \\ Edy Suandi Hamid \\ Fakultas Ekonomi Universitas Islam Indonesia
}

\begin{abstract}
This study identified KWLM management in public forest management and analyzed the effect of cooperative management in public forests management to economic resilience of society of KWLM members. It took at Koperasi Wana Lestari Menoreh in Kulon Progo.

This study used combination method with "KWLM management" and "sustainable forest management in public forest management" as independent variable and "economic resilience of society of KWLM members" as dependent variable. Sampling used purposive sampling method. Informants were representing management and members of the cooperative, and respondents were taken from 40 cooperative members.

This study concluded that KWLM management in public forests management was done with good cooperative management based on the cooperative principles so as to improved its members welfare and implementing sustainable forest management so it could produce forest products in a sustainable manner. Cooperative management in public forests management had positive effect on economic resilience of society of KWLM members.
\end{abstract}

Keywords: Management, Cooperative, Sustainable Forest Management, Public Forest, Economic Resilience of Society

\begin{abstract}
ABSTRAK
Penelitian ini bertujuan untuk mengetahui dan menganalisis manajemen KWLM dalam rangka pengelolaan hutan rakyat dan untuk menganalisis pengaruh manajemen koperasi dalam rangka pengelolaan hutan rakyat terhadap ketahanan ekonomi masyarakat anggota KWLM. Penelitian ini mengambil studi pada Koperasi Wana Lestari Menoreh di Kabupaten Kulon Progo, DIY.

Penelitian ini menggunakan metode penelitian kombinasi dengan variabel bebas manajemen KWLM dan manajemen hutan lestari dalam rangka pengelolaan hutan rakyat, serta variabel terikat ketahanan ekonomi
\end{abstract}


Imam Subekti, Edhi Martono, dan Edy Suandi Hamid -- Manajemen Koperasi Dalam Rangka Pengelolaan Hutan Rakyat Dan Pengaruhnya Terhadap Ketahanan Ekonomi Masyarakat (Studi Pada Koperasi Wana Lestari Menoreh Di Kabupaten Kulon Progo, DIY)

masyarakat anggota KWLM. Pengambilan sampel menggunakan metode purposive sampling. Informan mewakili pengurus dan anggota koperasi, dan responden sebanyak 40 orang anggota koperasi yang sudah bergabung minimal 2 tahun.

Dari hasil penelitian disimpulkan bahwa manajemen KWLM dalam rangka pengelolaan hutan rakyat dilakukan dengan manajemen usaha koperasi yang baik dilandasi prinsip-prinsip koperasi, sehingga dapat meningkatkan kesejahteraan anggotanya dan manajemen hutan lestari, sehingga dapat memproduksi hasil hutan secara berkelanjutan. Manajemen koperasi dalam rangka pengelolaan hutan rakyat berpengaruh positif terhadap ketahanan ekonomi masyarakat anggota KWLM.

Kata Kunci: Manajemen, Koperasi, Manajemen Hutan Lestari, Hutan Rakyat, Ketahanan Ekonomi Masyarakat

\section{PENGANTAR}

Hutan adalah sumber daya alam yang strategis. Namun banyaknya permasalahan dalam pengelolaan hutan di Indonesia justru merusak sumber daya hutan itu sendiri. Kebijakan pengelolaan hutan di Indonesia sejak pasca kemerdekaan hingga sekarang dapat dibagi menjadi 3 periode (Lindayati, 2002). Periode pasca kemerdekaan hingga pertengahan tahun 1980-an dikenal sebagai paradigma State Based Forest Management. Pada periode ini hutan dilihat sebagai sumber ekonomi negara yang identik dengan kayu dan masyarakat tidak dilibatkan dalam pengelolaan hutan. Pada periode sejak pertengahan tahun 1980-an hingga 1998, pemerintah mulai mengadopsi program hutan sosial (social forestry) dengan memberikan akses terhadap hutan kepada masyarakat lokal. Pada periode 1998 hingga sekarang, pengelolaan hutan beralih pada paradigma pengelolaan hutan berbasis komunitas (Community Based Forest Management / CBFM). Pada periode ini, keikutsertaan masyarakat semakin ditingkatkan dan mulai mendapatkan akses secara formal dengan porsi yang lebih besar dalam pengelolaan hutan. Salah satu bentuk pemberdayaan masyarakat dalam pembangunan kehutanan yaitu melalui pembangunan hutan rakyat. Hutan rakyat merupakan lahan milik rakyat yang ditanami dengan tanaman komoditi berupa tanaman kayu dengan tujuan agar lahan tersebut dapat berfungsi seperti kawasan hutan dan dapat memberikan nilai ekonomi yang optimal bagi pemiliknya.

Di Kabupaten Kulon Progo, luas hutan rakyat dari tahun ke tahun semakin meningkat. Berdasarkan data dari Dinas Pertanian dan Kehutanan Kabupaten Kulon Progo, pada tahun 2006 luas hutan rakyat di Kabupaten Kulon Progo 16.387,94 Ha dan pada tahun 2014 meningkat menjadi 20.392,30 Ha. Dalam rangka mengoptimalkan pengelolaan hutan rakyat di wilayah Kabupaten Kulon Progo, masyarakat mendirikan Koperasi Wana Lestari Menoreh (KWLM) pada tahun 2008. Koperasi ini dibentuk untuk meningkatkan partisipasi masyarakat dalam pengelolaan hutan dengan menerapkan manajemen hutan lestari. Koperasi merupakan bangun perusahaan yang sesuai dengan amanat UUD 1945 yaitu perekonomian disusun sebagai usaha bersama berdasar atas asas kekeluargaan (Baswir, 1997). Bentuk lembaga koperasi dipilih sebagai badan usaha bersama yang bertumpu pada prinsip ekonomi kerakyatan yang berdasarkan atas asas kekeluargaan. Koperasi memiliki ciri ganda yaitu memiliki unsur ekonomi dan unsur sosial (Hendrojogi, 
2004). Keberhasilan sebuah koperasi tidak hanya dilihat dari sisi usaha atau ekonominya saja, tetapi juga bagaimana prinsip-prinsip koperasi diterapkan dalam kegiatannya sehingga keberadaan koperasi tersebut mampu meningkatkan kesejahteraan anggotanya.

Dalam konsep ketahanan nasional, ketahanan ekonomi merupakan salah satu bagian dari 8 gatra ketahanan nasional. Ketahanan ekonomi suatu masyarakat tercermin dalam kondisi perekonomian masyarakat tersebut yang stabil, mandiri dan sejahtera. Kemampuan masyarakat dalam mengelola potensi sumber daya yang ada di wilayahnya menjadi salah satu faktor penting untuk dapat mewujudkan ketahanan ekonomi dalam masyarakat tersebut. Keberadaan Koperasi Wana Lestari Menoreh memberikan kontribusi terhadap ketahanan ekonomi masyarakat dengan banyaknya pemilik hutan rakyat yang bergabung menjadi anggota dan melakukan pengelolaan hutan rakyat secara lestari sehingga dapat meningkatkan kesejahteraan masyarakat dan menjaga kelestarian lingkungan yang juga menopang perekonomian masyarakat, terutama di bidang pertanian dan kehutanan.

Penelitian ini didasarkan atas beberapa teori yang berkaitan erat dengan tema yang diteliti.

Menurut Manullang (2012) manajemen mengandung 3 pengertian, yaitu manajemen sebagai suatu proses, manajemen sebagai kolektivitas orang-orang yang melakukan aktivitas manajemen, dan manajemen sebagai suatu ilmu dan seni. Manajemen adalah seni dan ilmu perencanaan, pengorganisasian, penyusunan, pengarahan, dan pengawasan sumber daya untuk tujuan yang sudah ditetapkan. Manajemen harus dapat mengelola segenap sumber daya yang dimiliki secara efektif dan efisien untuk mencapai tujuan organisasi (Robbins dan Coulter, 2012). Menurut Siagian (2007), keberhasilan organisasi untuk mencapai tujuan tergantung pada kemampuan manajer, ketersediaan tenaga operasional, ketersediaan anggaran, ketersediaan sarana dan prasarana kerja, mekanisme kerja organisasi, iklim kerja dan kerja sama dalam organisasi, dan situasi lingkungan.

Menurut International Cooperative Alliance (1995) koperasi adalah perkumpulan otonom dari orang-orang yang bergabung secara sukarela untuk memenuhi kebutuhan dan aspirasi ekonomi, sosial, dan budaya mereka yang sama melalui perusahaan yang dimiliki dan diawasi secara demokratis. Koperasi merupakan organisasi yang memiliki ciri ganda yaitu unsur ekonomi sekaligus unsur sosial (Hendrojogi, 2004). Sebagaimana amanat Undang-Undang Nomor 25 Tahun 1992 Tentang Koperasi, koperasi sebagai badan usaha harus bekerja secara efektif dan efisien menurut prinsip ekonomi untuk mengembangkan usahanya dan menghasilkan laba sebesar-besarnya untuk kesejahteraan anggota. Sebagai gerakan ekonomi kerakyatan, koperasi melandaskan kegiatannya pada prinsip-prinsip koperasi yaitu keanggotaan yang sukarela dan terbuka, pengawasan demokratis oleh anggota, partisipasi anggota dalam kegiatan ekonomi, otonomi dan kemandirian, pendidikan pelatihan dan penerangan, kerjasama antar koperasi, dan kepedulian terhadap masyarakat. 'Menurut Altman (2015), keberhasilan suatu koperasi sangat ditentukan oleh penerapan prinsip-prinsip koperasi, keberadaan pengurus dan manajer koperasi yang berkualitas dan berkompeten, 
Imam Subekti, Edhi Martono, dan Edy Suandi Hamid -- Manajemen Koperasi Dalam Rangka Pengelolaan Hutan Rakyat Dan Pengaruhnya Terhadap Ketahanan Ekonomi Masyarakat (Studi Pada Koperasi Wana Lestari Menoreh Di Kabupaten Kulon Progo, DIY)

transparansi dan akuntabilitas, dan rencana usaha yang baik dan berkelanjutan.

Hutan rakyat adalah hutan yang berada pada tanah yang dibebani hak milik (UU No 41 tahun 1999 Tentang Kehutanan). Hutan rakyat merupakan lahan milik rakyat yang ditanami jenis tanaman tertentu agar dapat berfungsi seperti kawasan hutan dan dapat memberikan nilai ekonomi bagi pemiliknya. Agar dapat menjaga kelestarian lingkungan dan memberikan hasil ekonomi secara berkelanjutan, dikembangkan sistem pengelolaan hutan rakyat dengan menerapkan manajemen hutan lestari. Manajemen hutan lestari menurut International Tropical Timber Organization (ITTO, 1998 dalam Lahjie, 2005) adalah proses mengelola hutan untuk menghasilkan barang dan jasa hutan tanpa merusak nilai dan produktivitas hutan di masa depan dan tanpa menyebabkan pengaruhpengaruh yang tidak diinginkan terhadap lingkungan fisik dan sosial. Terdapat beberapa unsur dalam manajemen hutan lestari yaitu kerangka kerja hukum dan kebijakan, produksi optimal dari hasil-hasil kehutanan secara berkelanjutan, perlindungan lingkungan, kesejahteraan masyarakat, dan terdapat pertimbangan khusus untuk hutan tanaman (Lahjie, 2005).

Ketahanan nasional merupakan kondisi dinamis suatu bangsa yang meliputi aspek kehidupan nasional yang terintegrasi dan berisi keuletan dan ketangguhan yang mengandung kemampuan mengembangkan kekuatan nasional dalam menghadapi dan mengatasi segala tantangan, ancaman, hambatan serta gangguan yang datang dari luar maupun dalam negeri yang langsung maupun tidak langsung membahayakan integritas, identitas, kelangsungan hidup bangsa dan negara serta perjuangan mengejar tujuan nasional (Lemhannas, 1997). Ketahanan ekonomi merupakan bagian dari ketahanan nasional dalam aspek ekonomi. Ketahanan ekonomi adalah kemampuan untuk memulihkan, mempertahankan dan mengembangkan kondisi perekonomian yang sehat. Briguglio, dkk., (2008) menjelaskan bahwa ketahanan ekonomi dipengaruhi oleh beberapa faktor yaitu stabilitas kondisi ekonomi makro, efisiensi pasar ekonomi mikro, tata pemerintahan yang baik dan pembangunan sosial. Menurut Hannan (2014), secara kelembagaan koperasi memiliki potensi untuk dapat meningkatkan kesejahteraan anggotanya, terlihat dari 3 aspek. Pertama, koperasi memiliki kapasitas untuk menyimpan, memproses dan menjual produk-produk anggotanya secara kolektif, sehingga dapat meningkatkan skala ekonomi usaha koperasi. Kedua, tujuan dari usaha koperasi adalah melayani kebutuhan anggota sehingga memudahkan anggota koperasi dalam memenuhi kebutuhannya. Ketiga, adanya kerja sama antar koperasi atau dengan badan usaha lainnya memungkinkan anggota koperasi untuk mendapatkan pelayanan melalui jaringan yang lebih luas. Potensi koperasi untuk meningkatkan kesejahteraan anggotanya memberikan kontribusi terhadap ketahanan ekonomi masyarakat.

Penelitian ini membahas tentang manajemen koperasi dalam rangka pengelolaan hutan rakyat dan pengaruhnya terhadap ketahanan ekonomi masyarakat pada Koperasi Wana Lestari Menoreh. Rumusan masalah dalam penelitian ini yaitu (1) Bagaimana manajemen Koperasi Wana Lestari Menoreh dalam rangka pengelolaan hutan rakyat di Kabupaten Kulon Progo, dan (2) Bagaimana pengaruh manajemen koperasi dalam rangka 
Tabel 1

Rumus Penilaian

\begin{tabular}{|c|c|c|c|}
\hline TAHAP & URAIAN & RUMUS & KETERANGAN \\
\hline 1 & $\begin{array}{l}\text { Pengisian data melalui } \\
\text { instrumen penelitian }\end{array}$ & & $\begin{array}{l}\text { Interpretasi nilai: } \\
\text { Nilai } 1=\text { sangat buruk/sangat rendah } \\
\text { Nilai } 2=\text { buruk/rendah } \\
\text { Nilai } 3=\text { sedang } \\
\text { Nilai } 4=\text { baik/tinggi } \\
\text { Nilai } 5 \text { = sangat baik/sangat tinggi }\end{array}$ \\
\hline 2 & $\begin{array}{l}\text { Menentukan nilai } \\
\text { indikator }\end{array}$ & $\begin{array}{l}\qquad \mathbf{X}_{\mathbf{n}_{\mathrm{i}}} \\
\sum \mathrm{X}_{\mathrm{i}}=\text { total nilai data } \\
\mathrm{n}_{\mathrm{i}}=\text { banyaknya data }\end{array}$ & $\begin{array}{l}\text { Interpretasi nilai: } \\
0>Z \leq 1=\text { sangat buruk/sangat rendah } \\
1>Z \leq 2=\text { buruk/rendah } \\
2>Z \leq 3=\text { sedang } \\
3>Z \leq 4=\text { baik/tinggi } \\
4>Z \leq 5=\text { sangat baik/sangat tinggi }\end{array}$ \\
\hline 3 & $\begin{array}{l}\text { Menentukan nilai } \\
\text { variabel }\end{array}$ & $\begin{array}{l}\qquad \frac{\sum \mathbf{X}_{\mathrm{i}}}{\mathbf{n}_{\mathbf{i}} * \mathbf{5}} \\
\sum \mathrm{X}_{\mathrm{i}}=\text { total nilai indikator } \\
\mathrm{n}_{\mathrm{i}}=\text { banyaknya indikator }\end{array}$ & $\begin{array}{l}\text { Interpretasi nilai: } \\
0>Z \leq 0,2=\text { sangat buruk/sangat rendah } \\
0,2>Z \leq 0,4=\text { buruk/rendah } \\
0,4>Z \leq 0,6=\text { sedang } \\
0,6>Z \leq 0,8=\text { baik/tinggi } \\
0,8>Z \leq 1,0=\text { sangat baik/sangat tinggi }\end{array}$ \\
\hline
\end{tabular}

Sumber: Dibuat oleh peneliti

pengelolaan hutan rakyat terhadap ketahanan ekonomi masyarakat anggota Koperasi Wana Lestari Menoreh.

Penelitian ini menggunakan metode penelitian kombinasi dengan menitikberatkan pada metode kualitatif sebagai metode primer dan metode kuantitatif sebagai metode sekunder. Pengambilan sampel dilakukan dengan metode purposive sampling (Creswell, 2009). Informan mewakili pengurus dan anggota koperasi, dan responden sebanyak 40 orang dari 1.484 populasi anggota koperasi yang sudah bergabung minimal 2 tahun. Pengumpulan data dilakukan dengan observasi, wawancara mendalam, kuesioner, studi dokumentasi dan studi kepustakaan. Analisis data kualitatif dilakukan melalui proses reduksi data, penyajian data dan penarikan kesimpulan. Data kuantitatif dinilai menggunakan skala Likert 1 sampai dengan 5 , dengan rumus penilaian seperti pada tabel 1 dan dianalisis menggunakan analisis regresi linier berganda.
Hubungan antar kelompok data pada tabel 1 tersebut dinyatakan dalam rumus : $\mathrm{Y}=$ $\beta_{0}+\beta_{1} X_{1}+\beta_{2} X_{2}$, dimana $Y$ adalah ketahanan ekonomi masyarakat, $\mathrm{X} 1$ adalah manajemen Koperasi Wana Lestari Menoreh, dan X2 adalah manajemen hutan lestari dalam rangka pengelolaan hutan rakyat.

Uji hipotesis menggunakan uji $\mathrm{F}$ dengan taraf signifikansi $0,05, \mathrm{df1}=2, \mathrm{df} 2=37$. Uji parsial menggunakan uji $\mathrm{T}$ dengan taraf signifikansi $0,05, \mathrm{df}=37$. Besarnya pengaruh dari variabel bebas $X_{1}$ dan $X_{2}$ terhadap variabel terikat $\mathrm{Y}$ ditentukan oleh nilai koefisien determinasi Adjusted R Square. Hasil analisis dari data kuantitatif kemudian diinterpretasikan dan digunakan sebagai pendukung data kualitatif.

\section{PEMBAHASAN}

\section{Manajemen Koperasi Wana Lestari Menoreh}

Koperasi Wana Lestari Menoreh (KWLM) merupakan koperasi di Kabupaten Kulon 
Imam Subekti, Edhi Martono, dan Edy Suandi Hamid -- Manajemen Koperasi Dalam Rangka Pengelolaan Hutan Rakyat Dan Pengaruhnya Terhadap Ketahanan Ekonomi Masyarakat (Studi Pada Koperasi Wana Lestari Menoreh Di Kabupaten Kulon Progo, DIY)

Progo yang memiliki usaha mengelola hutan rakyat. Koperasi ini diinisiasi melalui program Community Logging sebagai upaya untuk mendorong pengelolaan hutan secara lestari oleh komunitas untuk mewujudkan kelestarian ekologi, kelestarian ekonomi dan kelestarian sosial. KWLM terbentuk pada 2 Agustus 2008 dan mendapatkan pengesahan hukum pada tanggal 3 April 2009 melalui Keputusan Menteri Negara Koperasi dan Usaha Kecil dan Menengah Nomor: 29/BH/XV.3/2009 dengan sekretariat di J1. Dekso-Samigaluh km.1 Dusun Jogobayan, Desa Banjararum,
Kecamatan Kalibawang, Kabupaten Kulon Progo. Cakupan wilayah kerja yang menjadi fokus Koperasi Wana Lestari Menoreh saat ini meliputi 4 kecamatan yaitu Kecamatan Samigaluh, Kecamatan Kalibawang, Kecamatan Girimulyo, dan Kecamatan Nanggulan. Jumlah anggota koperasi pada tahun 2015 sebanyak 1.484 orang, dengan lahan kelola yang sudah memperoleh sertifikasi FSC (Forest Stewardship Council). seluas 700,417 Ha.

Untuk dapat menjalankan kegiatankegiatannya dalam rangka mencapai tujuantujuan koperasi, dibentuk struktur organisasi

Gambar 1

Struktur Organisasi Koperasi Wana Lestari Menoreh

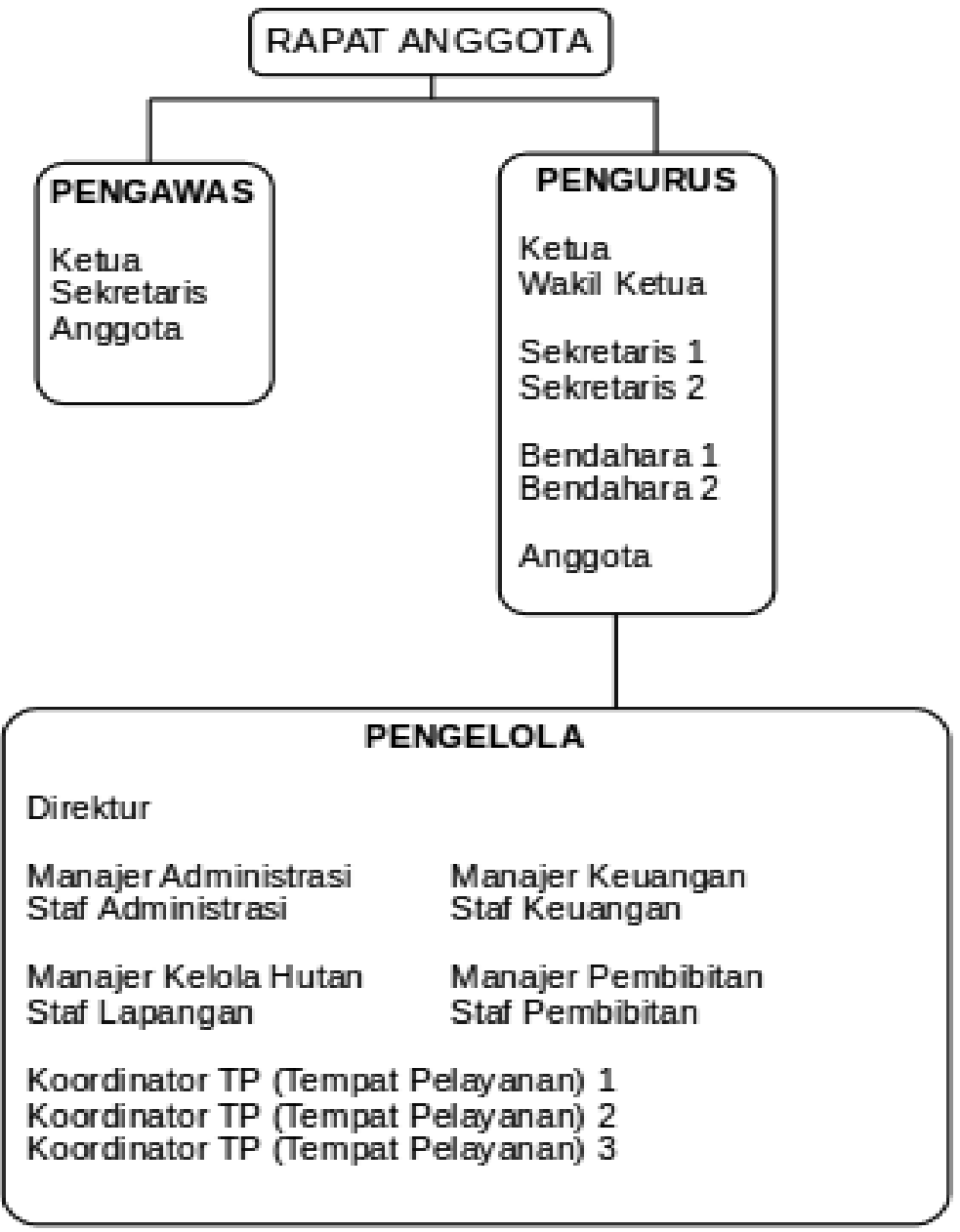

Sumber : KWLM, 2016 
Koperasi Wana Lestari Menoreh, terdiri dari Rapat Anggota, Pengurus Koperasi, Pengelola Koperasi dan Pengawas Koperasi, sebagaimana tampak pada gambar 1.

Rapat anggota merupakan pemegang kekuasaan tertinggi dalam koperasi. Rapat anggota diadakan sekurang-kurangnya sekali dalam setahun. Apabila terdapat persoalan yang memerlukan pemecahan dalam bentuk keputusan secara cepat, maka rapat anggota dapat dilaksanakan sewaktu-waktu. Pengurus koperasi dipilih dari dan oleh anggota dalam rapat anggota secara demokratis. Untuk meningkatkan profesionalisme dalam mengelola usaha koperasi, pengurus dapat mengangkat pengelola terdiri dari manajer dan karyawan untuk mengelola usaha koperasi. Pengawas koperasi bertugas mengawasi pengelolaan koperasi agar tidak terjadi penyimpangan.

Manajemen Koperasi Wana Lestari Menoreh dilaksanakan dengan menerapkan prinsip-prinsip koperasi dan menjalankan manajemen usaha koperasi yang baik. Pelaksanaan prinsip-prinsip koperasi diperlukan untuk menjamin tercapainya tujuan koperasi secara ekonomi maupun sosial.

Sesuai prinsip koperasi yang pertama, keanggotaan KWLM bersifat sukarela dan terbuka. Namun sesuai dengan wilayah kerja dan kegiatannya mengelola hutan rakyat, KWLM membatasi yang dapat diterima sebagai anggota koperasi harus berdomisili di Kabupaten Kulon Progo, merupakan anggota community logging, dan memiliki lahan yang dibuktikan kepemilikannya yang sah sebagai konsekuensi dari sertifikasi FSC (Forest Stewardship Council). untuk produk kayu KWLM.

Sesuai prinsip koperasi kedua yaitu pengawasan demokratis, setiap anggota ikut mengawasi jalannya koperasi. Pengawasan dilakukan secara internal oleh pengawas koperasi dan secara eksternal oleh akuntan publik untuk mengontrol jalannya koperasi agar sesuai dengan yang diharapkan. Pengurus menyampaikan laporan pertanggungjawaban pengurus kepada anggota dalam RAT meliputi laporan keuangan, laporan pelaksanaan kegiatan dan RAPBK. Pengawas menyampaikan laporan hasil pengawasan internal kepada anggota dalam RAT. Anggota dapat memberikan saran, kritik dan masukan kepada pengurus secara langsung maupun melalui RAT.

Sesuai prinsip koperasi ketiga yaitu partisipasi anggota dalam kegiatan ekonomi, KWLM selalu mendorong anggota untuk berpartisipasi dalam setiap kegiatan koperasi. Setiap anggota diwajibkan menyetor simpanan pokok dan simpanan wajib yang telah ditentukan. Anggota juga dapat menyimpan dananya berupa simpanan sukarela. Anggota juga menjual kayu hasil hutan rakyat miliknya kepada koperasi serta dilibatkan dalam kegiatan inventarisasi potensi tegakan. Pada saat pembagian SHU, setiap anggota menerima SHU sesuai dengan simpanan dan transaksi penjualan kayu.

Sesuai prinsip koperasi keempat, yaitu otonomi dan kemandirian, pelaksanaannya dapat dilihat dari proses pengambilan kebijakan, keputusan dalam manajemen koperasi. Sebagai badan yang otonom dan mandiri, segala kebijakan dan keputusan KWLM ditetapkan melalui rapat anggota.

Sesuai prinsip koperasi yang kelima yaitu pendidikan, pelatihan dan penerangan, KWLM menyelenggarakan pendidikan dan pelatihan bagi anggota agar dapat memahami kegiatan koperasi sebagai bentuk dari community 
Imam Subekti, Edhi Martono, dan Edy Suandi Hamid -- Manajemen Koperasi Dalam Rangka Pengelolaan Hutan Rakyat Dan Pengaruhnya Terhadap Ketahanan Ekonomi Masyarakat (Studi Pada Koperasi Wana Lestari Menoreh Di Kabupaten Kulon Progo, DIY)

logging dan pengelolaan hutan secara lestari. KWLM juga melaksanakan pelatihan bagi manajemen koperasi untuk meningkatkan kapasitasnya dalam mengelola koperasi. Bagi masyarakat, KWLM melakukan sosialisasi tentang community logging dan pengelolaan hutan secara lestari ke desa-desa di wilayah kelolanya.

Sesuai prinsip koperasi keenam yaitu kerjasama antar koperasi, KWLM menjalin kerjasama dengan beberapa pihak dalam rangka menjalankan pengelolaan hutan rakyat secara lestari dan memenuhi kebutuhan anggota. Untuk memperkuat kapasitas dalam pengelolaan hutan rakyat secara lestari, KWLM bekerjasama dengan lembagalembaga riset dan donor yang memiliki perhatian terhadap lingkungan, terutama ekosistem hutan. KWLM juga bekerja sama dengan koperasi-koperasi yang memiliki usaha sejenis membentuk dalam rangka penguatan kelembagaan pengelola hutan rakyat bersertifikat FSC. Untuk memenuhi kebutuhan anggota, KWLM menjalin kerja sama dengan Koperasi CUKATA dengan memfasilitasi anggota untuk dapat meminjam uang ke Koperasi CUKATA dengan menjaminkan tegakan pohon yang dimilikinya.

Prinsip koperasi ketujuh yaitu kepedulian terhadap masyarakat, mencerminkan adanya unsur sosial dalam kegiatan koperasi. Kegiatan KWLM mengelola hutan rakyat secara lestari memberikan dampak bagi masyarakat di sekitarnya. KWLM secara aktif ikut menjaga kelestarian alam di wilayah kelolanya dengan penerapan JTT (Jatah Tebang Tahunan), cara-cara pemanenan yang memperhatikan kelestarian lingkungan dan mencegah penggunaan bahan kimia berbahaya serta melakukan identifikasi kawasan yang memiliki nilai konservasi tinggi dan secara aktif ikut melindungi satwa, sumber air, dan situs budaya yang ada di dalamnya.

Keberhasilan koperasi sebagai badan usaha ditentukan oleh manajemen usaha yang baik, yaitu dengan adanya pengurus dan pengelola koperasi yang berkualitas, transparansi dan akuntabilitas, serta rencana usaha yang baik dan berkelanjutan. Keberadaan pengurus dan manajer koperasi yang berkualitas diperlukan untuk memimpin organisasi agar dapat berjalan efektif dan efisien dalam mencapai tujuan. Pengurus, pengawas dan pengelola koperasi memiliki tingkat pendidikan minimal SMA, sedangkan karyawan diangkat melalui seleksi yang dilakukan oleh pengurus. KWLM juga menyelenggarakan pelatihan untuk meningkatkan pengetahuan dan keterampilan pengelola koperasi. Transparansi dan akuntabilitas diperlukan agar tidak terjadi penyimpangan dalam pengelolaan koperasi. Pertanggungjawaban pengurus koperasi disampaikan pada rapat anggota berupa laporan pertanggungjawaban meliputi laporan kelembagaan, laporan usaha dan laporan keuangan. Pengawas juga menyampaikan laporan hasil pengawasan pada rapat anggota. Rencana kerja dan rencana anggaran pendapatan dan belanja untuk tahun berjalan dibacakan dan disahkan dalam rapat anggota. Akuntabilitas koperasi ditunjukkan oleh hasil pemeriksaan yang dilakukan secara internal oleh pengawas koperasi maupun eksternal oleh pemeriksa independen dari kantor akuntan publik. Rencana usaha yang baik dan berkelanjutan diperlukan sebagai acuan dalam menjalankan kegiatan usaha agar dapat berkembang secara berkelanjutan.

Dalam pengelolaan hutan rakyat KWLM terdapat 3 aspek yang melandasinya 
yaitu kapasitas, kualitas dan kontinyuitas. Mengenai kapasitas, KWLM melakukan inventarisasi lahan dan potensi tegakan untuk mengetahui seberapa besar potensi dari hutan rakyat yang dikelolanya. Mengenai kualitas, KWLM memberlakukan tebang pilih dalam pemanenan, sehingga kayu yang dijual oleh KWLM adalah kayu yang berkualitas dan layak di pasaran. KWLM juga memberikan pelatihan kepada anggota mengenai silvikultur mulai dari proses penanaman, penjarangan, pemotongan, dan perawatan pohon. Mengenai kontinyuitas, KWLM memberlakukan Jatah Tebangan Tahunan (JTT) dan mengganti setiap batang pohon yang ditebang dengan 10 bibit pohon secara gratis. Pasca penebangan, dilakukan monitoring terhadap kondisi tegakan, kondisi kawasan dan satwa di kawasan tersebut.

Untuk mengukur manajemen Koperasi Wana Lestari Menoreh, dilakukan penilaian berdasarkan data kuantitatif yang diperoleh dari jawaban responden. Nilai tiap-tiap indikator dihitung menggunakan rumus:

$\frac{\sum x_{1}}{n_{1}}$ dimana $\sum \mathrm{X}_{\mathrm{i}}=$ total nilai komponen, dan $\mathrm{n}_{\mathrm{i}}=$ banyaknya komponen.

Dari perhitungan tersebut diperoleh hasil, bahwa pelaksanaan prinsip-prinsip koperasi sebesar: $\frac{3,05+4+4,15+3,88+3,23+4,08+3,90=3,75}{7}$, dan manajemen usaha koperasi sebesar:

$$
\frac{3,65+3,95+3,70=3,77}{7}
$$

Selanjutnya nilai variabel bebas manajemen Koperasi Wana Lestari Menoreh dihitung menggunakan rumus:

$\frac{\sum X_{i}}{\operatorname{nix} 5}$ dimana $\sum X_{i}=$ total nilai indikator, dan $n_{i}=$ banyaknya indikator
Dari perhitungan tersebut diperoleh hasil, bahwa manajemen Koperasi Wana Lestari Menoreh sebesar $\frac{3,75+3,77}{2 \times 5}=0,75$

Dari hasil perhitungan tersebut dapat diinterpretasikan bahwa manajemen Koperasi Wana Lestari Menoreh telah dijalankan dengan baik. Penilaian terhadap manajemen Koperasi Wana Lestari Menoreh secara lengkap disajikan pada tabel 2 .

\section{Manajemen Hutan Lestari Dalam Rangka Pengelolaan Hutan Rakyat}

Manajemen hutan lestari merupakan pengelolaan hutan yang mengedepankan kelestarian untuk mendapatkan hasil yang berkelanjutan. Menurut Lahjie (2005), terdapat beberapa unsur dalam manajemen hutan lestari yaitu kerangka kerja hukum dan kebijakan, produksi optimal dari hasil-hasil kehutanan secara berkelanjutan, perlindungan lingkungan, kesejahteraan masyarakat, dan pertimbangan khusus untuk hutan tanaman. Hutan yang dikelola oleh KWLM merupakan hutan rakyat milik anggota yang pada umumnya ditanami jenis tanaman bermacam-macam sehingga unsur pertimbangan khusus untuk hutan tanaman diabaikan.

Kerangka kerja hukum dan kebijakan pada KWLM diwujudkan dalam legalitasnya sebagai badan hukum melalui Keputusan Menteri Negara Koperasi dan Usaha Kecil dan Menengah Nomor: 29/BH/XV.3/2009 tanggal 3 April 2009 tentang Pengesahan Akta Pendirian Koperasi. Legalitas hukum KWLM diperlukan untuk dapat melakukan tindakantindakan hukum dalam rangka melakukan kegiatan usahanya mengelola hutan rakyat milik anggota koperasi. Legalitas hukum juga diperlukan sebagai salah satu prinsip yang harus dipenuhi untuk mendapatkan 
Imam Subekti, Edhi Martono, dan Edy Suandi Hamid -- Manajemen Koperasi Dalam Rangka Pengelolaan Hutan Rakyat Dan Pengaruhnya Terhadap Ketahanan Ekonomi Masyarakat (Studi Pada Koperasi Wana Lestari

Tabel 2

Penilaian Terhadap Manajemen Koperasi Wana Lestari Menoreh

\begin{tabular}{|c|c|c|c|}
\hline Indikator & Komponen & Pelaksanaan & Nilai \\
\hline \multirow[t]{7}{*}{$\begin{array}{l}\text { Pelaksanaan } \\
\text { prinsip-prinsip } \\
\text { koperasi }\end{array}$} & $\begin{array}{l}\text { Keanggotaan } \\
\text { bersifat sukarela dan } \\
\text { terbuka }\end{array}$ & $\begin{array}{l}\text { - Keanggotaan KWLM bersifat sukarela dan terbuka, namun dengan } \\
\text { syarat berdomisili di wilayah Kabupaten Kulon Progo, menjadi anggota } \\
\text { Community Logging, dan memiliki lahan }\end{array}$ & 3,05 \\
\hline & $\begin{array}{l}\text { Pengawasan } \\
\text { demokratis }\end{array}$ & $\begin{array}{l}\text { - Audit dilakukan secara internal oleh Pengawas Koperasi dan eksternal } \\
\text { oleh akuntan publik. } \\
\text { - Pengurus dan pengawas koperasi menyampaikan laporan pertanggung } \\
\text { jawaban kepada Rapat Anggota. } \\
\text { - Anggota dapat memberikan saran, kritik dan masukan secara langsung } \\
\text { maupun melalui Rapat Anggota. }\end{array}$ & 4,00 \\
\hline & $\begin{array}{l}\text { Partisipasi anggota } \\
\text { dalam kegiatan } \\
\text { ekonomi }\end{array}$ & $\begin{array}{l}\text { - Anggota menyetor simpanan pokok, simpanan wajib dan simpanan } \\
\text { sukarela sebagai modal koperasi. } \\
\text { - Anggota menjual kayu hasil hutan rakyat miliknya melalui koperasi. } \\
\text { - Anggota terlibat dalam inventarisasi potensi tegakan. } \\
\text { - Pembagian SHU dan besarnya transaksi penjualan kayu yang dilakukan } \\
\text { melalui koperasi. }\end{array}$ & 4,15 \\
\hline & $\begin{array}{l}\text { Otonomi dan } \\
\text { kemandirian }\end{array}$ & $\begin{array}{l}\text { - Segala kebijakan ditetapkan oleh koperasi secara otonom melalui rapat } \\
\text { anggota. }\end{array}$ & 3,88 \\
\hline & $\begin{array}{l}\text { Pendidikan pelatihan } \\
\text { dan penerangan }\end{array}$ & $\begin{array}{l}\text { - KWLM mengadakan sosialisasi dan pelatihan pengelolaan hutan rakyat } \\
\text { secara lestari } \\
\text { - KWLM melaksanakan pelatihan bagi manajemen koperasi untuk } \\
\text { meningkatkan kapasitasnya dalam mengelola koperasi. }\end{array}$ & 3,23 \\
\hline & $\begin{array}{l}\text { Kerjasama antar } \\
\text { koperasi }\end{array}$ & $\begin{array}{l}\text { - KWLM bekerjasama dengan lembaga riset dan donor dalam pengelolaan } \\
\text { hutan rakyat secara lestari } \\
\text { - KWLM bekerjasama dengan Koperasi CUKATA, untuk memenuhi } \\
\text { kebutuhan anggota yang memerlukan dana pinjaman dengan menjaminkan } \\
\text { tegakan pohon yang dimilikinya. } \\
\text { - KWLM bekerjasama dengan koperasi sejenis lainnya di Indonesia } \\
\text { membentuk PT. SOBI untuk memperkuat kapasitas usaha jual beli kayu } \\
\text { bersertifikat FSC. }\end{array}$ & 4,08 \\
\hline & $\begin{array}{l}\text { Kepedulian terhadap } \\
\text { masyarakat }\end{array}$ & $\begin{array}{l}\text { - Koperasi secara langsung ikut menjaga kelestarian alam } \\
\text { - Koperasi secara aktif ikut melindungi satwa, sumber air, dan situs } \\
\text { budaya }\end{array}$ & 3,90 \\
\hline \multicolumn{2}{|c|}{ Pelaksanaan prinsip-prinsip koperasi } & $\frac{3,05+4,00+4,15+3,88+3,23+4,08+3,90}{7}$ & 3,75 \\
\hline \multirow[t]{2}{*}{$\begin{array}{l}\text { Pelaksanaan } \\
\text { manajemen } \\
\text { usaha koperasi }\end{array}$} & $\begin{array}{l}\text { Sumber Daya } \\
\text { Manusia }\end{array}$ & $\begin{array}{l}\text { - Tingkat pendidikan pengurus dan pengawas koperasi } 9 \text { orang }(75 \%) \\
\text { setingkat Diploma/ Sarjana dan } 3 \text { orang }(25 \%) \text { setingkat SMA } \\
\text { - Masih terjadi penyimpangan yang dilakukan oleh beberapa petugas } \\
\text { lapangan }\end{array}$ & 3,65 \\
\hline & $\begin{array}{l}\text { Transparansi dan } \\
\text { akuntabilitas }\end{array}$ & $\begin{array}{l}\text { - Pemeriksaan keuangan dari auditor independen terhadap dana hibah } \\
\text { HIVOS mendapatkan hasil WTP } \\
\text { - Pemeriksaan internal oleh pengawas koperasi dari tahun 2011- } 2015 \\
\text { dengan hasil "baik". } \\
\text { - Anggota mendapatkan informasi tentang posisi keuangan serta program- } \\
\text { program koperasi pada saat rapat anggota dan setiap saat melalui media } \\
\text { sosial }\end{array}$ & 3,95 \\
\hline
\end{tabular}


Sambungan dari halaman 167

\begin{tabular}{|c|c|c|c|}
\hline Indikator & Komponen & Pelaksanaan & Nilai \\
\hline & $\begin{array}{l}\text { Rencana usaha } \\
\text { yang baik dan } \\
\text { berkelanjutan }\end{array}$ & $\begin{array}{l}\text { - Pengelolaan hutan rakyat memperhatikan } 3 \text { aspek yaitu kapasitas, kualitas } \\
\text { dan kontinyuitas dengan melakukan inventarisasi potensi, memberlakukan } \\
\text { tebang pilih, JTT dan pembibitan. } \\
\text { - Luas lahan kelola meningkat dari } 110,00 \mathrm{Ha} \text { pada tahun } 2010 \text { menjadi } \\
\text { 700,41 Ha pada } 2015 \\
\text { - Potensi tegakan meningkat dari } 2.161,70 \mathrm{~m}^{3} \text { pada tahun } 2010 \text { menjadi } \\
\text { 10.718,26 m } \\
\text { - JTT meningkat dari } 336,758 \mathrm{~m}^{3} \text { pada tahun } 2010 \text { menjadi } 2.080,988 \mathrm{~m}^{3} \\
\text { pada tahun } 2015 \\
\text { - Nilai penjualan pada tahun } 2015 \text { mencapai Rp.1.345.729.688,00 }\end{array}$ & 3,70 \\
\hline \multicolumn{2}{|c|}{ Pelaksanaan manajemen koperasi } & $\frac{3,65+3,95+3,70}{3}$ & 3,77 \\
\hline $\begin{array}{l}\text { Manajemen } \\
\text { Lestari Men }\end{array}$ & $\begin{array}{l}\text { perasi Wana } \\
\text { h }\end{array}$ & $\frac{\text { Pelaksanaan prinsip-prinsip koperasi }+ \text { Pelaksanaan manajemen koperasi }}{2 \times 5}=\frac{3,754+3,767}{2 \times 5}$ & $\begin{array}{c}0,75 \\
\text { (BAIK) }\end{array}$ \\
\hline
\end{tabular}

Sumber: Analisis data primer

sertifikasi FSC (Forest Stewardship Council). Status kepemilikan hutan rakyat yang dikelola koperasi berada di tanah milik anggota, dibuktikan dengan dokumen-dokumen kepemilikan lahan yang sah dan diakui pemerintah sehingga keterlacakan asal usul sumber bahan baku produk-produk kayu dapat dipertanggung jawabkan dan berkelanjutan.

Produksi optimal dari hasil-hasil kehutanan secara berkelanjutan tergambar pada pelaksanaan rencana pengelolaan hutan KWLM yang selalu memperhatikan aspek kapasitas, kualitas dan kontinyuitas. Koperasi menentukan produk kayu yang dikelola, melakukan inventarisasi potensi tegakan, menetapkan pengaturan tebangan, dan penyediaan bibit tanaman. KWLM menetapkan jenis tanaman yang dikelola yaitu jati (Tectona grandis), mahoni (Swietenia $s p$ ), sonokeling (Dalbergia lattifolia) dan sengon atau albasia (Paraseriantes falcataria). KWLM melakukan inventarisasi potensi tegakan secara rutin untuk mengetahui potensi dan kondisi tegakan, mengetahui struktur tegakan hutan, perkembangan pertumbuhan pohon, kondisi lahan hutan, dan menyediakan informasi untuk perencanaan pengelolaan hutan jangka panjang. Dalam pemanenan, KWLM mengatur batasan tebangan dengan memberlakukan tebang pilih yaitu batasan minimal diamater pohon yang boleh ditebang, penentuan JTT (Jatah Tebang Tahunan), tidak mengizinkan penebangan sekaligus pada satu lahan, dan bagi anggota yang pohonnya belum layak tebang tetapi memerlukan dana untuk memenuhi kebutuhan dapat memperoleh pinjaman dengan jaminan tegakan pohon. Untuk penyediaan bibit tanaman, KWLM telah membuat areal pembibitan sendiri yang berlokasi di Desa Pagerharjo. KWLM menyediakan 10 bibit tanaman untuk setiap pohon yang ditebang secara gratis bagi anggotanya.

Perlindungan terhadap lingkungan hidup dalam manajemen hutan lestari mengacu pada kelestarian ekologi. KWLM memberlakukan prosedur dalam pemanenan untuk mempertahankan kelestarian hutan dan mencegah erosi serta longsor. KWLM melakukan monitoring internal secara berkala 
Imam Subekti, Edhi Martono, dan Edy Suandi Hamid -- Manajemen Koperasi Dalam Rangka Pengelolaan Hutan Rakyat Dan Pengaruhnya Terhadap Ketahanan Ekonomi Masyarakat (Studi Pada Koperasi Wana Lestari Menoreh Di Kabupaten Kulon Progo, DIY)

terhadap kondisi alam, flora yang dilindungi, populasi kayu, dan penggunaan pestisida. KWLM juga melakukan identifikasi kawasan bernilai konservasi tinggi (NKT) di wilayah kelolanya dan secara aktif ikut menjaga kelestariannya. Terdapat 3 kawasan NKT di wilayah pengelolaan hutan rakyat KWLM yaitu kawasan NKT-1 yang mempunyai tingkat keanekaragaman hayati tinggi, kawasan NKT-5 yang mempunyai fungsi penting untuk pemenuhan kebutuhan dasar masyarakat lokal, dan kawasan NKT-6 yang mempunyai fungsi penting untuk identitas budaya tradisional komunitas lokal. KWLM mencegah penggunaan bahan-bahan kimia berbahaya dengan tidak menganjurkan penggunaan pestisida atau bahan kimia apapun pada tanaman yang dikelola oleh anggotanya.

Pengelolaan hutan KWLM memberikan dampak yang positif pada kesejahteraan masyarakat. Kesejahteraan anggota koperasi mengalami peningkatan karena dapat menjual kayu dengan harga lebih baik, adanya transparansi dalam menentukan volume kayu, mendapatkan bibit tanaman secara gratis dan juga bisa memperoleh pinjaman dari koperasi dengan jaminan tegakan pohon yang dimilikinya, meskipun belum layak tebang. Dengan adanya sertifikasi FSC (Forest Stewardship Council), anggota KWLM dapat menjual kayunya dengan harga yang lebih tinggi, sehingga dapat memberikan kontribusi bagi pendapatan masyarakat. Keuntungan KWLM yang diperoleh dari hasil penjualan kayu dari anggota akan dikembalikan kepada anggota dalam bentuk SHU. Bergabungnya masyarakat pemilik hutan rakyat dalam KWLM memperpendek rantai pemasaran kayu hasil hutan rakyat sehingga meningkatkan efisiensi pemasarannya. Masyarakat di wilayah kelola KWLM juga mendapatkan manfaat dari pengelolaan hutan rakyat KWLM yang dilakukan secara lestari yaitu terjaganya kelestarian lingkungan, mempertahankan sumber-sumber air untuk masyarakat, dan mencegah terjadinya erosi serta longsor. Terjaganya kelestarian lingkungan dan sumber-sumber air menopang kegiatan ekonomi masyarakat yang sebagian besar di sektor pertanian.

Untuk mengukur manajemen hutan lestari dalam rangka pengelolaan hutan rakyat dilakukan penilaian berdasarkan data kuantitatif yang diperoleh dari jawaban responden. Nilai variabel bebas manajemen hutan lestari dalam rangka pengelolaan hutan rakyat dihitung menggunakan rumus:

$\sum X_{\mathrm{i}}$

$\overline{n_{i} \times 5}$ dimana $\sum X_{i}=$ total nilai indikator, dan $n_{i}=$ banyaknya indikator

Dari perhitungan tersebut diperoleh hasil, bahwa manajemen hutan lestari dalam rangka pengelolaan hutan rakyat sebesar:

$$
\frac{4,35+3,80+4,00+3,83}{4 \times 5}=0,83
$$

Dari hasil perhitungan tersebut dapat diinterpretasikan bahwa manajemen hutan lestari dalam rangka pengelolaan hutan rakyat telah dijalankan dengan sangat baik oleh KWLM. Penilaian terhadap manajemen hutan lestari dalam rangka pengelolaan hutan rakyat secara lengkap disajikan pada tabel 3.

\section{Kendala yang Dihadapi}

Pengelolaan hutan rakyat yang dilakukan oleh KWLM selama ini telah berjalan dengan baik. Namun saat ini wilayah pengelolaan hutan KWLM masih terbatas pada 4 kecamatan dari 12 kecamatan yang ada di Kabupaten 
Tabel 3

Penilaian Terhadap Manajemen Hutan Lestari Dalam Rangka Pengelolaan Hutan Rakyat

\begin{tabular}{|c|c|c|}
\hline Indikator & Pelaksanaan & Nilai \\
\hline $\begin{array}{l}\text { Kerangka kerja hukum dan } \\
\text { kebijakan }\end{array}$ & $\begin{array}{l}\text { - Memiliki bentuk badan hukum koperasi dengan pengesahan melalui Kep } \\
\text { Menteri Negara KUKM No: 29/BH/XV.3/2009 tanggal } 3 \text { April } 2009 \\
\text { - Memiliki arah kebijakan yang jelas dalam pengelolaan hutan rakyat dengan } \\
\text { adanya sertifikasi FSC } \\
\text { - Lahan yang dikelola koperasi merupakan milik anggota yang dibuktikan } \\
\text { dengan bukti kepemilikan yang sah }\end{array}$ & 3,80 \\
\hline $\begin{array}{l}\text { Produksi optimal dari } \\
\text { hasil-hasil kehutanan secara } \\
\text { berkelanjutan }\end{array}$ & $\begin{array}{l}\text { - Memiliki rencana pengelolaan hutan yang jelas serta menjamin kelestarian } \\
\text { lingkungan dan keberlanjutan produksi }\end{array}$ & 4,00 \\
\hline Perlindungan lingkungan & $\begin{array}{l}\text { - Memiliki data wilayah yang bernilai konservasi tinggi dan mengeluarkan } \\
\text { kebijakan untuk melindungi dan melestarikannya, baik merupakan habitat } \\
\text { tanaman atau hewan langka dan dilindungi (NKT 1), sumber air dan konservasi } \\
\text { tanah (NKT 5), dan situs budaya serta peninggalan sejarah (NKT 6) }\end{array}$ & 3,83 \\
\hline Kesejahteraan masyarakat & $\begin{array}{l}\text { - Anggota koperasi mengalami peningkatan karena dapat menjual kayu } \\
\text { dengan harga lebih baik, adanya transparansi dalam menentukan volume } \\
\text { kayu, mendapatkan bibit tanaman secara gratis dan juga bisa memperoleh } \\
\text { pinjaman dengan jaminan tegakan pohon yang dimilikinya, meskipun belum } \\
\text { layak tebang. } \\
\text { - Bagi masyarakat, manajemen hutan lestari berdampak pada terjaganya } \\
\text { kelestarian lingkungan, mempertahankan sumber-sumber air untuk konsumsi } \\
\text { masyarakat dan pertanian, serta mencegah terjadinya erosi serta longsor. }\end{array}$ & \\
\hline $\begin{array}{l}\text { Manajemen Hutan Lestari } \\
\text { Dalam Pengelolaan Hutan } \\
\text { Rakyat }\end{array}$ & $\frac{4,35+3,80+4,00+3,83}{4 \times 5}$ & $\begin{array}{c}\text { 0,83 } \\
\text { (SANGAT } \\
\text { BAIK) } \\
\end{array}$ \\
\hline
\end{tabular}

Sumber: Analisis data primer

Kulon Progo yaitu Kalibawang, Samigaluh, Girimulyo dan Nanggulan dengan luas lahan kelola yang sudah tersertifikasi 700,41 Ha atau 3,4\% dari seluruh lahan hutan rakyat di wilayah ini seluas 20.392,30 Ha. KWLM masih menemui beberapa kendala, baik secara internal maupun eksternal.

Secara internal, KWLM mengalami kendala keterbatasan sumber daya manusia, keterbatasan finansial, dan keterbatasan di bidang usaha. Semakin bertambahnya jumlah anggota dan wilayah kelola KWLM tidak dibarengi dengan peningkatan kapasitas pengelola menyebabkan intensitas pendampingan dan pengawasan kepada anggota koperasi menurun. Kurangnya pendampingan dan pengawasan mengakibatkan berkurangnya loyalitas anggota kepada koperasi dalam menjual kayu hasil hutan rakyat miliknya. Dalam hal keanggotaan, 55 persen anggota koperasi berusia di atas 50 tahun. Hal ini berdampak pada sulitnya sosialisasi tentang aturan pengelolaan hutan rakyat yang dilakukan oleh KWLM, baik dalam tata cara pemanenan maupun penjualan kayu ke koperasi.

Sebagai sebuah badan usaha, kekuatan finansial merupakan salah satu faktor yang menentukan keberhasilan usaha. Karena keterbatasan finansial, KWLM belum mampu mengelola hutan rakyat di seluruh wilayah Kabupaten Kulon Progo, karena memerlukan biaya yang cukup besar untuk melakukan sertifikasi, sosialisasi, pelatihan 
Imam Subekti, Edhi Martono, dan Edy Suandi Hamid -- Manajemen Koperasi Dalam Rangka Pengelolaan Hutan Rakyat Dan Pengaruhnya Terhadap Ketahanan Ekonomi Masyarakat (Studi Pada Koperasi Wana Lestari Menoreh Di Kabupaten Kulon Progo, DIY)

dan pendampingan anggota, serta pembayaran kayu anggota yang dibeli oleh koperasi. Untuk mengurangi biaya sertifikasi, KWLM bekerjasama dengan koperasi lainnya yang bergerak di bidang pengelolaan hutan membentuk PT. SOBI (Sosial Bisnis Indonesia) untuk mengajukan sertifikasi bersama sebagai group sertification. Keterbatasan finansial juga mengakibatkan keterlambatan dalam pembayaran kayu kepada anggota, akibatnya beberapa anggota yang membutuhkan dana cepat memilih menjual kayunya pada pedagang atau pihak lain yang sanggup membayar kontan.

Di bidang usaha, KWLM masih kekurangan stok kayu albasia untuk memenuhi permintaan pasar. Saat ini, permintaan kayu albasia bersertifikat FSC (Forest Stewardship Council), sebesar $80 \mathrm{~m}^{3}$ sampai dengan $100 \mathrm{~m}^{3}$ per bulan, dan pada tahun 2016 ada tambahan permintaan sebesar $1.500 \mathrm{~m}^{3}$ per bulan. Permintaan tersebut jauh lebih besar dari JTT untuk kayu albasia sebesar $1.255 \mathrm{~m}^{3}$. Akibatnya KWLM belum mampu memenuhi seluruh permintaan tersebut padahal kayu albasia memiliki nilai ekonomi yang cukup baik. KWLM juga terkendala usaha kayu olahan yang dilakukan melalui PT. PNU (POROS NUSANTARA) dihentikan karena mengalami kerugian terus menerus. Bidang usaha yang dijalankan oleh KWLM menjadi terbatas pada jual beli kayu dalam bentuk log dan tidak memiliki unit usaha sendiri yang dapat ikut menyerap produksi dan memberikan nilai tambah terhadap produk yang dihasilkan.

Secara eksternal, KWLM terkendala masalah kondisi alam wilayah Kabupaten Kulon Progo yang sangat bervariasi, perekrutan anggota, dan persaingan dengan pedagang kayu lokal. Sebagian besar lahan hutan rakyat di Kabupaten Kulon Progo berada di bagian utara yang merupakan perbukitan Menoreh. Kecamatan Girimulyo, Kalibawang dan Samigaluh saat ini sudah masuk dalam wilayah kelola KWLM. Namun Kecamatan Kokap belum masuk wilayah kelola KWLM karena letaknya cukup jauh dan sulit dijangkau dari koperasi. Wilayah bagian tengah merupakan daerah peralihan yang juga memiliki potensi hutan rakyat, meskipun tidak seluas bagian utara. Yang sudah masuk dalam wilayah kelola KWLM di bagian tengah yaitu Kecamatan Nanggulan. Wilayah bagian selatan merupakan dataran rendah yang potensi hutan rakyatnya relatif kecil.

Untuk meningkatkan kapasitas usahanya, perekrutan anggota sangat penting bagi KWLM karena hutan yang dikelolanya merupakan hutan rakyat milik anggota, sehingga penambahan jumlah anggota akan menambah luas lahan hutan yang dikelola. KWLM melakukan perekrutan anggota dengan melakukan sosialisasi tentang community logging dan pengelolaan hutan rakyat secara lestari yang dilakukan oleh koperasi. Namun tidak semua yang mengikuti sosialisasi tersebut mau bergabung dengan KWLM.

Dari sisi usaha, KWLM bersaing dengan pedagang lokal dalam membeli kayu. Hal ini karena KWLM tidak membatasi anggota untuk menjual kayunya kepada siapa saja. Konsekuensinya, KWLM harus bersaing dengan pedagang lokal dalam menawar kayu milik anggotanya. Dalam hal ini, KWLM memberlakukan mekanisme pembelian volume yang menjadikan harga kayu lebih transparan. Meskipun demikian, terkadang ada pedagang kayu yang menawar dengan harga yang lebih tinggi, sehingga anggota menjual 
kayunya ke pedagang dengan pertimbangan harga. Selain itu, kurangnya pendampingan kepada anggota juga mempengaruhi loyalitas anggota untuk menjual kayunya ke koperasi.

\section{Ketahanan ekonomi masyarakat anggota Koperasi Wana Lestari Menoreh}

Ketahanan ekonomi adalah kemampuan untuk memulihkan, mempertahankan dan mengembangkan kondisi perekonomian yang sehat. Ketahanan ekonomi dipengaruhi oleh beberapa faktor yaitu stabilitas kondisi ekonomi makro, efisiensi pasar ekonomi mikro, tata pemerintahan yang baik dan pembangunan sosial (Briguglio, dkk., 2008). Pada lingkup masyarakat anggota Koperasi Wana Lestari Menoreh, indikator yang dapat diamati dari ketahanan ekonomi masyarakat yaitu perkembangan usaha koperasi, keberlanjutan usaha koperasi, efisiensi pemasaran, nilai jual produk koperasi, tingkat pendapatan anggota koperasi, pemenuhan kebutuhan anggota koperasi, serta tingkat pengetahuan dan keterampilan anggota koperasi.

Usaha koperasi yang terus berkembang mencerminkan kemampuan untuk mengembangkan perekonomian. Perkembangan usaha KWLM dapat dilihat dari kemampuan produksinya yang terus meningkat seiring peningkatan JTT sebagai kapasitas produksi maksimal dari $336,758 \mathrm{~m}^{3}$ pada tahun 2010 menjadi $2.080,988 \mathrm{~m}^{3}$ pada tahun 2015. Hasil analisis keuangan yang dilakukan oleh pengawas koperasi menunjukkan tingkat likuiditas 2,14, solvabilitas 2,36 dan rentabilitas 0,11. Ini berarti KWLM memiliki kemampuan untuk memenuhi kewajiban finansialnya, baik kewajiban yang harus segera dipenuhi maupun kewajiban finansial jika dilikuidasi. Tingkat rentabilitas menunjukkan bahwa KWLM telah mampu menghasilkan laba 11 persen dari modal sendiri yang dimiliki.

Keberlanjutan usaha menunjukkan kemampuan untuk mempertahankan perekonomian. Pengelolaan hutan rakyat secara lestari memungkinkan KWLM untuk terus mempertahankan kemampuan usahanya. KWLM memberlakukan JTT untuk membatasi jumlah pohon yang ditebang setiap tahun dan memberikan bibit secara gratis sebanyak 10 bibit untuk setiap pohon yang ditebang kepada anggota yang menjual kayunya ke koperasi. Hal ini dapat menjamin ketersediaan stok kayu. Kebijakan tebang pilih juga dapat menjamin kualitas kayu yang dijual oleh KWLM. Ini akan mempertahankan pasar bagi penjualan kayu KWLM, karena konsumen akan memilih kayu yang berkualitas.

Efisiensi pemasaran dapatmemperpendek rantai pemasaran yang berdampak bagi keberlanjutan pemasaran produk koperasi. Ini juga mempengaruhi kemampuan untuk mempertahankan dan mengembangkan perekonomian koperasi. KWLM menjalin kerja sama dengan perusahaan-perusahaan pengolahan kayu bersertifikat FSC (Forest Stewardship Council), untuk memasok kebutuhan kayu mereka. Adanya kerja sama ini dapat menjamin ketersediaan pasar untuk produk kayu yang dihasilkan KWLM. Kerja sama ini juga menjadikan rantai pemasaran kayu lebih efisien yaitu dari anggota dijual ke koperasi, kemudian langsung ke perusahaan pengolahan kayu bersertifikat FSC (Forest Stewardship Council). Ini juga membantu anggota koperasi memperluas akses pasar untuk kayunya.

Sertifikasi FSC (Forest Stewardship Council) yang dimiliki oleh KWLM memberikan nilai tambah bagi kayu anggota 
Imam Subekti, Edhi Martono, dan Edy Suandi Hamid -- Manajemen Koperasi Dalam Rangka Pengelolaan Hutan Rakyat Dan Pengaruhnya Terhadap Ketahanan Ekonomi Masyarakat (Studi Pada Koperasi Wana Lestari Menoreh Di Kabupaten Kulon Progo, DIY)

koperasi. KWLM memberlakukan cara jual beli kayu berdasarkan volume dan kualitas kayu setelah berada di pinggir jalan yang dapat dilalui sarana transportasi. Penebangan dan pelangsiran kayu ke pingir jalan dapat dilakukan sendiri oleh anggota koperasi atau dapat dibantu oleh koperasi dengan biaya ditanggung oleh anggota koperasi. Dengan cara demikian, penentuan harga kayu menjadi lebih transparan serta menguntungkan kedua belah pihak. Harga yang diperoleh petani jika menjual kayunya ke koperasi bisa 15 persen sampai dengan 20 persen lebih tinggi jika dibandingkan dengan harga putus ke pedagang lokal.

Pendapatan merupakan salah satu ukuran kesejahteraan yang menjadi bagian dari ketahanan ekonomi. KWLM hanya memanen pohon milik anggota yang sudah layak tebang, sehingga kualitas kayunya layak di pasaran. Pada saat layak tebang, KWLM membeli kayu anggota untuk jenis kayu jati umur 16 tahun dengan diameter 22 sampai dengan $28 \mathrm{~cm}$ dan panjang $100 \mathrm{~cm}$ seharga Rp 2.100.000,- per $\mathrm{m}^{3}$, kayu mahoni umur 12 tahun dengan diameter 20 sampai dengan 27 $\mathrm{cm}$ dan panjang $150 \mathrm{~cm}$ seharga $\mathrm{Rp} 775.000$,per $\mathrm{m}^{3}$, dan kayu sengon atau albasia umur 5 tahun dengan panjang $130 \mathrm{~cm}$ dan diameter 19 sampai dengan 24 cm seharga Rp 900.000,per $\mathrm{m}^{3}$.

Kesejahteraan dalam aspek ekonomi tidak hanya dilihat dari pendapatan saja, tetapi juga dari pemenuhan kebutuhan. Sebagai badan usaha yang berwatak sosial, KWLM berusaha untuk dapat memenuhi kebutuhan anggotanya. Pada umumnya, anggota menjual kayu untuk memenuhi kebutuhan. Mereka menjadikan kayu sebagai tabungan yang akan dijual pada saat membutuhkan seperti untuk biaya sekolah, biaya pernikahan, membangun rumah dan kebutuhan lainnya. Namun karena KWLM memberlakukan tebang pilih, anggota koperasi tidak dapat menjual kayu yang belum layak tebang. Oleh karena itu, bagi anggota yang kayunya belum layak tebang, kayunya dapat dijadikan jaminan untuk mendapatkan pinjaman dengan adanya kerja sama dengan Koperasi CUKATA sebesar 60 persen dari taksiran harga kayunya. Pada saat kayu jaminan tersebut sudah layak tebang dan kemudian ditebang, nilai kayu akan dihitung secara riil. Jika ada kelebihan dari harga kayu akan dikembalikan kepada anggota tersebut.

Pengetahuan dan keterampilan diperlukan untuk dapat menjalankan dan mengembangkan kegiatan usaha yang menopang perekonomian. Pengetahuan dan keterampilan juga diperlukan untuk memulihkan perekonomian yang menurun karena sesuatu hal. KWLM menyelenggarakan pendidikan dan pelatihan agar anggota dapat memahami kegiatan koperasi dalam pengelolaan hutan secara lestari. Pelatihan diberikan kepada anggota mengenai silvikultur tanaman, mulai dari proses penanaman, penjarangan, pemotongan dan perawatan pohon. Dengan adanya pelatihan tersebut, anggota koperasi memiliki pengetahuan dan keterampilan yang cukup dalam mengelola hutan rakyat miliknya. KWLM juga melaksanakan pelatihan bagi manajemen koperasi untuk meningkatkan kapasitasnya dalam mengelola dan mengembangkan usaha koperasi. Pengetahuan dan keterampilan anggota koperasi serta kemampuan manajemen koperasi mencerminkan kemampuan untuk memulihkan, mempertahankan dan mengembangkan perekonomian masyarakat anggota koperasi. 
Untuk mengukur ketahanan ekonomi masyarakat anggota Koperasi Wana Lestari Menoreh dilakukan penilaian berdasarkan data kuantitatif yang diperoleh dari jawaban responden. Nilai variabel ketahanan ekonomi masyarakat anggota Koperasi Wana Lestari Menoreh dihitung menggunakan rumus:

$$
\frac{\sum X_{i}}{n_{i} \times 5} \text { dimana } \sum X_{i}=\text { total nilai indikator, }
$$
dan $\mathrm{n}_{\mathrm{i}}=$ banyaknya indikator

Dari perhitungan tersebut diperoleh hasil, bahwa ketahanan ekonomi masyarakat anggota Koperasi Wana Lestari Menoreh sebesar

$$
\frac{4,18+4,18+3,35+4,20+3,10+4,03+3,25=0,75}{7 \times 5}
$$

Dari hasil perhitungan tersebut dapat diinterpretasikan bahwa ketahanan ekonomi masyarakat anggota Koperasi Wana Lestari Menoreh dalam kondisi baik. Penilaian terhadap ketahanan ekonomi masyarakat anggota KWLM secara lengkap disajikan pada tabel 4 .

\section{Pengaruhnya Terhadap Ketahanan Ekonomi Masyarakat Anggota Koperasi Wana Lestari Menoreh}

Pengaruh manajemen koperasi dan manajemen hutan lestari dalam pengelolaan hutan rakyat terhadap ketahanan ekonomi masyarakat anggota Koperasi Wana Lestari Menoreh dirumuskan dalam bentuk persamaan regresi berganda: $Y=\beta_{0}+\beta_{1} X_{1}+\beta_{2} X_{2}$

Berdasarkan hasil pengujian menggunakan analisis regresi berganda diperoleh nilai $\beta_{0}=0,016 ; \beta_{1}=0,831$; dan $\beta_{2}=0,137$, sehingga diperoleh persamaan regresi: $\mathrm{Y}=0,016+0,831 \mathrm{X}_{1}+0,137 \mathrm{X}_{2 \text {, dimana }}$ Nilai $F_{u j i}=19,587>F_{\text {tabel }}=3,252$. Nilai $t_{u j i}$ pada variabel $\mathrm{X}_{1}=3,365>\mathrm{t}_{\text {tabel }}=1,687$. Nilai $\mathrm{t}_{\mathrm{uji}}$ pada variabel $\mathrm{X}_{2}=0,666<\mathrm{t}_{\text {tabel }}=1,687$. Nilai koefisien determinasi Adjusted $R$ Square 0,488 .

Dari hasil analisis data di atas, diperoleh beberapa kesimpulan. Pertama, dari hasil uji $\mathrm{F}$ diketahui bahwa persamaan regresi $\mathrm{Y}=0,016$ $+0,831 \mathrm{X}_{1}+0,137 \mathrm{X}_{2}$ signifikan dan dapat digunakan sebagai alat prediksi. Kedua, dari hasil uji $\mathrm{T}$ diketahui bahwa secara parsial, pengaruh variabel bebas $X_{1}$ terhadap variabel terikat $Y$ signifikan, sedangkan pengaruh variabel bebas $\mathrm{X}_{2}$ terhadap variabel terikat $\mathrm{Y}$ tidak signifikan. Ketiga, besarnya pengaruh manajemen Koperasi Wana Lestari Menoreh dan manajemen hutan lestari dalam rangka pengelolaan hutan rakyat terhadap ketahanan ekonomi masyarakat anggota KWLM yaitu 48,8 persen.

Manajemen Koperasi Wana Lestari Menoreh memiliki pengaruh yang signifikan terhadap ketahanan ekonomi masyarakat anggota KWLM. Ini terlihat dari hasil uji parsial yaitu nilai $\mathrm{t}_{\mathrm{uji}}$ pada variabel $\mathrm{X}_{1}=3,365>$ $\mathrm{t}_{\text {tabel }}=1,687$ dan juga dari persamaan regresinya yaitu $\mathrm{Y}=0,016+0,831 \mathrm{X}_{1}+0,137 \mathrm{X}_{2}$. Nilai $\beta_{1=} 0,831$ menunjukkan besarnya pengaruh manajemen Koperasi Wana Lestari Menoreh terhadap ketahanan ekonomi masyarakat anggota KWLM.

Manajemen koperasi yang baik dilandasi prinsip-prinsip koperasi dalam kegiatannya menjadikan KWLM mampu mengelola segenap sumber daya yang dimiliki secara efektif dan efisien untuk meningkatkan kesejahteraan anggotanya. Prinsip-prinsip koperasi merupakan ketentuan-ketentuan dalam pelaksanaan kegiatan koperasi yang membedakannya dengan badan usaha lain dan menjadikan koperasi sebagai badan yang memiliki ciri ganda yaitu unsur ekonomi sekaligus unsur sosial. Penerapan prinsip- 
Imam Subekti, Edhi Martono, dan Edy Suandi Hamid -- Manajemen Koperasi Dalam Rangka Pengelolaan Hutan Rakyat Dan Pengaruhnya Terhadap Ketahanan Ekonomi Masyarakat (Studi Pada Koperasi Wana Lestari

Tabel 4

Penilaian Terhadap Ketahanan Ekonomi Masyarakat Anggota Koperasi Wana Lestari Menoreh

\begin{tabular}{rlc}
\hline Indikator & \multicolumn{1}{c}{ Pelaksanaan } & Nilai \\
\hline Perkembangan & - JTT sebagai kapasitas produksi maksimal meningkat dari 336,758 $\mathrm{m}^{3}$ pada tahun 2010 & 4,18 \\
usaha koperasi & menjadi 2.080,988 $\mathrm{m}^{3}$ pada 2015 & \\
& - Hasil analisa keuangan pengawas koperasi menunjukkan tingkat likuiditas 2,14, solvabilitas \\
& 2,36 dan rentabilitas 0,11
\end{tabular}

Keberlanjutan

- JTT membatasi jumlah penebangan pohon setiap tahun dan penggantian bibit untuk setiap pohon yang ditebang dapat menjamin tetap tersedianya stok kayu yang dapat diproduksi

usaha koperasi oleh koperasi

Efisiensi pemasaran - Rantai pemasaran kayu lebih efisien dari anggota ke koperasi, kemudian ke perusahaan pengolahan kayu bersertifikat FSC

- Koperasi membantu anggota memperluas akses pasar kayu dari hutan rakyat miliknya

Nilai jual produk - Nilai jual kayu bersertifikat FSC melalui koperasi 15\% s.d 20\% lebih tinggi daripada harga pasar lokal

koperasi

- Namun jika terjadi harga putus, nilai jual kayu dibandingkan dengan harga di pasar lokal menjadi tidak dapat dipastikan

Tingkat pendapatan - Pendapatan dari hasil penjualan kayu tidak tentu, karena anggota KWLM umumnya menjual anggota koperasi kayu sesuai kebutuhannya.

- KWLM membeli kayu anggota jenis kayu jati umur 16 tahun dengan diameter $22-28 \mathrm{~cm}$ dan panjang $100 \mathrm{~cm}$ seharga Rp 2.100.000,00 per $\mathrm{m}^{3}$, kayu mahoni umur 12 tahun dengan diameter 20-27 $\mathrm{cm}$ dan panjang $150 \mathrm{~cm}$ seharga $\mathrm{Rp} 775.000,00$ per $^{3}$, dan kayu albasia umur 5 tahun dengan panjang $130 \mathrm{~cm}$ dan diameter $19-24 \mathrm{~cm}$ seharga $\mathrm{Rp} 900.000,00 \mathrm{per}^{3}$.

Pemenuhan - Anggota dapat menjual kayunya kepada koperasi untuk memenuhi kebutuhannya

kebutuhan anggota - Anggota yang memerlukan dana tetapi pohonnya belum layak tebang dapat memperoleh koperasi pinjaman dengan menjaminkan tegakan pohon senilai dengan pinjamannya melalui koperasi CUKATA.

Pengetahuan dan - Koperasi melaksanakan pelatihan kepada anggotanya tentang pengelolaan hutan rakyat yang lestari

anggota koperasi. - Koperasi melaksanakan pelatihan kepada manajemen koperasi untuk meningkatkan kapasitasnya dalam mengelola koperasi

\begin{tabular}{lcc}
\hline $\begin{array}{l}\text { Ketahanan } \\
\text { ekonomi } \\
\text { masyarakat }\end{array}$ & $\frac{4,18+4,18+3,35+4,20+3,10+4,03+3,25}{7 \times 5}$ & 0,75 \\
anggota KWLM & & (BAIK) \\
\hline
\end{tabular}

Sumber: Analisis data primer

prinsip koperasi secara konsisten menjadikan

KWLM dapat berkembang dengan tetap memiliki unsur ekonomi dan unsur sosial yang menjadi ciri khas koperasi. Kegiatan usaha yang dijalankan oleh KWLM tidak sematamata menghasilkan keuntungan ekonomi saja, tetapi juga berdampak pada peningkatan kesejahteraan anggota.

Manajemen koperasi yang memiliki sumber daya manusia berkualitas, transparan dan akuntabel, serta memiliki rencana usaha yang baik dan berkelanjutan menjadikan KWLM mampu mengembangkan usahanya dalam pengelolaan hutan rakyat secara lestari dalam rangka mencapai tujuan koperasi yaitu memajukan kesejahteraan ekonomi dan sosial anggota, membangun dan mengembangkan potensi dan kemampuan ekonomi anggota dengan pelestarian hutan rakyat, serta menyiapkan kebutuhan anggota. Sumber daya 
manusia yang baik dari pengurus koperasi mampu menjalankan kegiatan usaha serta program-program pengelolaan hutan rakyat secara lestari sehingga koperasi dapat semakin berkembang. Transparansi dan akuntabilitas koperasi menjamin pelaksanaan programprogram koperasi sesuai dengan rencana dan memperkecil terjadinya penyimpangan dalam pengelolaan koperasi. Adanya rencana usaha yang baik dan berkelanjutan menjadikan KWLM tidak hanya mampu menjalankan usahanya dengan baik, tetapi juga mampu mengembangkan dan menjaga keberlanjutan usahanya.

Dengan demikian, manajemen Koperasi Wana Lestari Menoreh telah memberikan kontribusi dalam memperkuat ketahanan ekonomi masyarakat anggota koperasi. Hal ini terlihat dari perkembangan dan keberlanjutan usaha koperasi, peningkatan pendapatan anggota dari hasil penjualan kayu, kebutuhan anggota dapat terpenuhi dari hasil penjualan kayu atau pun adanya akses untuk mendapatkan bantuan berupa pinjaman dengan jaminan tegakan pohon, dan peningkatan pengetahuan serta keterampilan anggota koperasi dalam mengelola hutan rakyat miliknya.

Berdasarkan hasil uji parsial nilai $\mathrm{t}_{\mathrm{uji}}$ pada variabel $\mathrm{X}_{2}=0,666<\mathrm{t}_{\text {tabel }}=1,687$, pengaruh manajemen hutan lestari dalam rangka pengelolaan hutan rakyat terhadap ketahanan ekonomi masyarakat anggota KWLM tidak signifikan. Namun berdasarkan persamaan regresi $\mathrm{Y}=0,016+0,831 \mathrm{X}_{1}+$ $0,137 \mathrm{X}_{2}$ variabel bebas manajemen hutan lestari dalam rangka pengelolaan hutan rakyat memiliki pengaruh yang positif terhadap ketahanan ekonomi masyarakat anggota KWLM meskipun relatif kecil, ditunjukkan dengan nilai $\beta_{2}$ yaitu 0,137 .
Manajemen hutan lestari merupakan pengelolaan hutan untuk menghasilkan barang dan jasa hutan tanpa merusak nilai dan produktivitas hutan di masa depan dan tanpa menyebabkan pengaruh-pengaruh yang tidak diinginkan terhadap lingkungan fisik dan sosial. Pelaksanaan manajemen hutan lestari oleh KWLM dapat mempertahankan kapasitas produksi dalam rangka menjaga keberlanjutan usaha jual beli kayu yang dijalankan oleh koperasi dengan adanya aturan JTT (Jatah Tebang Tahunan) yang membatasi jumlah pohon yang boleh ditebang dalam satu tahun dan pemberian bibit gratis untuk ditanam menggantikan pohon yang ditebang. Sertifikasi FSC (Forest Stewardship Council) yang dimiliki KWLM dalam kegiatannya mengelola hutan rakyat secara lestari memberikan nilai tambah bagi kayu yang dihasilkan oleh anggota koperasi sehingga harga jualnya menjadi lebih tinggi dibandingkan harga di pasar lokal. Adanya sertifikasi FSC (Forest Stewardship Council) juga membuka peluang pasar menjadi lebih besar, terutama akses ke perusahaanperusahaan yang bergerak di bidang furnitur dan kayu olahan bersertifikat. KWLM ikut berkontribusi dalam memperpendek rantai pemasaran kayu sehingga menjadi lebih efisien, dari anggota ke koperasi kemudian langsung ke industri kayu olahan, tanpa melewati pengepul seperti yang terjadi di pasar lokal. Dengan demikian manajemen hutan lestari dalam rangka pengelolaan hutan rakyat turut berkontribusi terhadap ketahanan ekonomi masyarakat anggota koperasi dengan menjamin keberlanjutan usaha, meningkatkan nilai jual kayu anggota, dan menjadikan rantai pemasaran kayu lebih efisien.

Berdasarkan hasil uji F, secara bersamasama variabel bebas manajemen Koperasi 
Imam Subekti, Edhi Martono, dan Edy Suandi Hamid -- Manajemen Koperasi Dalam Rangka Pengelolaan Hutan Rakyat Dan Pengaruhnya Terhadap Ketahanan Ekonomi Masyarakat (Studi Pada Koperasi Wana Lestari Menoreh Di Kabupaten Kulon Progo, DIY)

Wana Lestari Menoreh dan manajemen hutan lestari dalam rangka pengelolaan hutan rakyat memiliki pengaruh yang signifikan terhadap ketahanan ekonomi masyarakat anggota KWLM. Besarnya pengaruh kedua variabel tersebut ditunjukkan oleh persamaan regresi $\mathrm{Y}=0,016+0,831 \mathrm{X}_{1}+0,137 \mathrm{X}_{2}$. Berdasarkan nilai koefisien determinasi Adjusted $R$ Square, kedua variabel tersebut memberikan pengaruh sedang terhadap ketahanan ekonomi masyarakat anggota KWLM sebesar 48,8 persen.

Hasil analisis tersebut menjelaskan bahwa manajemen koperasi yang melandaskan kegiatannya pada prinsip-prinsip koperasi dan manajemen hutan lestari dalam rangka pengelolaan hutan rakyat berbanding lurus dengan kondisi ketahanan ekonomi masyarakat anggota koperasi. Semakin baik manajemen koperasi dan manajemen hutan lestari, maka ketahanan ekonomi masyarakat anggota koperasi juga semakin baik. Pada Koperasi Wana Lestari Menoreh, manajemen koperasi dijalankan dengan baik dan manajemen hutan lestari dijalankan dengan sangat baik, maka anggota KWLM memiliki ketahanan ekonomi masyarakat yang baik. Anggota KWLM memiliki kemampuan yang baik untuk memulihkan, mempertahankan dan mengembangkan kondisi perekonomian yang sehat.

Manajemen koperasi yang baik dilandasi prinsip-prinsip koperasi dalam kegiatannya menjadikan KWLM mampu mengelola segenap sumber daya yang dimiliki secara efektif dan efisien untuk meningkatkan kesejahteraan anggotanya. Adanya sumber daya manusia berkualitas, transparansi dan akuntabilitas, serta rencana usaha yang baik dan berkelanjutan menjadikan KWLM mampu mengembangkan dan menjaga keberlanjutan usahanya dalam pengelolaan hutan rakyat secara lestari. Pelaksanaan manajemen hutan lestari oleh KWLM dapat mempertahankan kapasitas produksi dengan adanya JTT (Jatah Tebang Tahunan) dan pemberian bibit gratis untuk ditanam menggantikan pohon yang ditebang. Sertifikasi FSC (Forest Stewardship Council) yang diperoleh KWLM memberikan nilai tambah bagi kayu anggota koperasi, membuka peluang pasar menjadi lebih besar, dan menjadikan rantai pemasaran kayu lebih efisien.

\section{SIMPULAN}

Berdasarkan hasil penelitian dan pembahasan diperoleh simpulan sebagai berikut.

Pertama, manajemen Koperasi Wana Lestari Menoreh dalam rangka pengelolaan hutan rakyat di Kabupaten Kulon Progo dilakukan dengan manajemen usaha koperasi yang baik dilandasi oleh prinsip-prinsip koperasi sehingga dapat meningkatkan kesejahteraan anggotanya dan menerapkan manajemen hutan lestari sehingga dapat memproduksi hasil hutan secara berkelanjutan dengan tetap menjaga kelestarian lingkungan.

Kedua, manajemen koperasi dalam rangka pengelolaan hutan rakyat berbanding lurus dan memiliki pengaruh sedang terhadap ketahanan ekonomi masyarakat anggota Koperasi Wana Lestari Menoreh. Semakin baik manajemen koperasi dan manajemen hutan lestari dalam pengelolaan hutan rakyat, maka ketahanan ekonomi masyarakat anggota koperasi akan semakin baik.

Berdasarkan hasil penelitian di atas, disampaikan rekomendasi sebagai berikut.

Pertama, terkait keterbatasan sumber daya manusia, KWLM perlu meningkatkan 
kapasitas pengelola koperasi baik dari segi jumlah maupun kualitasnya melalui pelatihanpelatihan dan meningkatkan intensitas pelatihan, pendampingan dan pengawasan kepada anggota untuk meningkatkan pengetahuan dan keterampilan anggota dalam mengelola hutan rakyat, serta menjaga loyalitas mereka agar tetap menjual kayunya melalui koperasi.

Kedua, terkait keterbatasan finansial, KWLM perlu terus mendorong peningkatan kemampuan finansial koperasi melalui simpanan wajib dan simpanan sukarela dari anggota koperasi dan mendorong para mitra koperasi agar bersedia menanamkan investasinya di KWLM.

Ketiga, terkait keterbatasan di bidang usaha, KWLM perlu mengembangkan usaha pengolahan kayu berupa industri meubel mau pun handycraft dengan menggandeng para pengrajin lokal sebagai industri hilir yang dapat ikut menyerap kayu yang dihasilkan anggota koperasi, mengembangkan produkproduk hutan lainnya terutama tanaman obat, dan mengembangkan tanaman-tanaman khas daerah perbukitan Menoreh untuk pendidikan.

Keempat, terkait kondisi alam Kabupaten Kulon Progo yang bervariasi, KWLM perlu membuat suatu strategi pengembangan wilayah kelolanya dengan memfokuskan pada daerah-daerah yang memiliki potensi hutan rakyat yang besar dan membuat perwakilan di tiap-tiap wilayah untuk memudahkan pelayanan kepada anggota koperasi.

Kelima, terkait perekrutan anggota, KWLM perlu meningkatkan sosialisasi tentang kegiatan KWLM dalam mengelola hutan rakyat secara lestari kepada masyarakat Kabupaten Kulon Progo. Perlu adanya dukungan dari pemerintah daerah dan dinas terkait untuk mendorong pengelolaan hutan rakyat sebagai pengelolaan kawasan yang terpadu dengan menerapkan manajemen hutan lestari melalui Koperasi Wana Lestari Menoreh agar dapat memberikan manfaat yang optimal bagi kesejahteraan masyarakat, namun tetap terjaga kelestariannya.

Keenam, terkait persaingan usaha dengan pedagang kayu lokal, KWLM perlu selalu memantau harga kayu di pasar lokal dan menyesuaikan harga beli kayunya ke anggota koperasi agar dapat memberikan harga yang lebih baik dari pedagang lokal, namun tetap menguntungkan koperasi. KWLM juga perlu meningkatkan pendampingan dan pengawasan kepada anggota koperasi untuk menjaga loyalitas mereka agar tetap menjual kayu melalui koperasi karena lebih menguntungkan.

\section{DAFTAR PUSTAKA}

Altman, Morris, 2015, Cooperative Organizations As An Engine of Equitable Rural Economic Development, Journal of Co-operative Organization and Management, Vol. 3, Hal. 14-23.

Baswir, Revrisond, 1997, Agenda Ekonomi Kerakyatan, Yogyakarta, Pustaka Pelajar. Briguglio, L., Cordina, G., Farrugia, N., dan Vella, S., 2008, "Economic Vulnerability and Resilience Concepts and Measurements", Research Paper No. 2008/55, Helsinki, UNU-WIDER.

Creswell, John W., 2009, Research Design Qualitative, Quantitative And Mixed Methods Approaches, Thousand Oaks, SAGE Publications, Inc.

Hannan, Rowshan, 2014, The institution of co-operation: A pathway from governance 
Imam Subekti, Edhi Martono, dan Edy Suandi Hamid -- Manajemen Koperasi Dalam Rangka Pengelolaan Hutan Rakyat Dan Pengaruhnya Terhadap Ketahanan Ekonomi Masyarakat (Studi Pada Koperasi Wana Lestari Menoreh Di Kabupaten Kulon Progo, DIY)

to spillover and poverty reduction, Journal of Co-operative Organization and Management, Vol. 2, Hal. 34-42.

Hendrojogi, 2004, Koperasi Asas-asas, Teori, dan Praktik, Jakarta, Rajawali Pers.

International Co-operative Alliance, 1995, Co-opertive identity, values \& principles, $<$ http://www.ica.coop/en/whats-co-op/ co-operative-identity-values-principles $>$ (diakses 4 November 2015)

Lahjie, Abubakar M., 2005, Ekoforestri dalam Panduan Manajemen Hutan Lestari, Samarinda, Universitas Mulawarman.

Lemhannas, 1997, Ketahanan Nasional, Jakarta, Balai Pustaka.

Lindayati, Rita, 2002, "Ideas and Insitutions in social forestry policy" dalam Which Way Forward? People, Forest, and
Policymaking in Indonesia, diedit oleh Coffer dan Ida Ayu, Bogor, Centre for International Forestry Research.

Manullang, M., 2012, Dasar-Dasar Manajemen, Yogyakarta, Gajah Mada University Press.

Robbins, S., dan Coulter, M., 2012, Management $11^{\text {th }}$ Edition, New Jersey, Pearson Education.Inc

Siagian, Sondang P., 2007, Fungsi-Fungsi Manajerial, Jakarta, Bumi Aksara.

\section{Peraturan Perundangan}

Undang-Undang Nomor 25 tahun 1992 Tentang Koperasi

Undang-Undang Nomor 41 tahun 1999

Tentang Kehutanan 